\title{
PERHITUNGAN BIAYA POKOK PENYEDIAAN (BPP) TENAGA LISTRIK PER GOLONGAN PELANGGAN STUDI KASUS PT PLN (PERSERO) SISTEM SULSELTRABAR
}

\author{
Sahabuddin Hay \\ Staf Pengajar Jurusan Teknik Elektro Fakultas Teknik Universitas Halu Oleo, Kendari \\ Email:mjjamal16@yahoo.com
}

\begin{abstract}
Abstrak
Penelitian ini melakukan kajian untuk menentukan besaran Biaya Pokok Penyediaan (BPP) tenaga listrik, menentukan besaran BPP tenaga listrik per jenis tegangan dan menentukan besaran BPP-TL per golongan pelanggan pada PT. PLN (PERSERO) sistem Sulseltrabar. Penelitian ini menggunakan data realisasi biaya operasi pada periode 1 Januari sampai dengan 31 Desember 2007 yang berupa data produksi dan penjualan tenaga listrik, daya tersambung (kVA) dan pemakaian energi $(\mathrm{kWh})$. Dari data tersebut, dihitung biaya tersambung dan biaya pemakaian energi, biaya total pokok penyediaan tenaga listrik (BPP TL), BPP per-jenis tegangan, alokasi losses pada volume penjualan, alokasi biaya variabel pada volume penjualan, alokasi biaya variabel pada daya tersambung, BPP TT,TM dan TR, BPP pergolongan pelanggan, dan biaya tetap,variabel dan total.
\end{abstract}

Kata Kunci : BPP, PLN Sulseltrabar, produksi,listrik, biaya

\begin{abstract}
The calculation on the overall main cost of the electricity supply (BPP) per-group of consumer in the case study of PT PLN (Persero) System of Sulseltrabar. The purpose of this study is to determine the overall main cost of the electricity supply $(B P P)$, to determine the cost of electricity supply per-type of voltage and to determine the cost of the electricity supply per-group of customers at the PT PLN (Persero) Sulseltrabar system. This study uses the data of the operating cost in the period of 1 January to 31 December 2007 in the form of the production and electricity sale, the connected power capacity $(\mathrm{kVA})$ and the energy consumption $(\mathrm{kWh})$. From the obtained data, it calculates the connected cost and the electricity consumption cost, the total cost of supplying electricity ( $B P P T L)$, the cost of power supply per-type voltage, the allocation of losses in the sales volume, the allocation of variable cost in the sale volume, the allocation of variable cost in the connected power, the cost of power supply for TT, TM and TR, the cost of power supply per-type of customers, and the fixed, variable and total costs.
\end{abstract}

Keywords : BPP, PLN Sulseltrabar, production, electrcity, cost

\section{Pendahuluan}

Tenaga listrik sangat berpengaruh pada pertumbuhan dan perkembangan ekonomi di suatu negara. Oleh karena itu, penetapan kebijakan tenaga listrik di suatu negara akan sangat mempengaruhi pertumbuhan dan perkembangan ekonomi.

Penetapan kebijakan tenaga listrik oleh pemerintah juga merupakan salah satu langkah pemerintah dalam mengatur perekonomian negara, suatu usaha yang sangat membutuhkan investasi untuk menjamin keberlangsungannya untuk masa yang akan datang.

Penyediaan tenaga listrik dapat berlangsung dengan baik apabila tersedia dana investasi yang baru dari pihak lain atau penyedia listrik telah memperoleh laba (margin) yang dapat dipergunakan untuk investasi. Jika perusahaan penyedia listrik memperoleh laba, maka penyedia listrik tersebut dapat memberikan sebagian keuntungan untuk investasi. 
Salah satu upaya untuk memperoleh laba dalam penyediaan listrik dapat dilakukan melalui penetapan tarif. Di dalam menghitung tarif dasar listrik (TDL), acuan pokok harga jual tenaga listrik yang digunakan adalah biaya pokok penyediaan (BPP) tenaga listrik, yang meliputi pembangkitan, transmisi dan distribusi (Depkeu, 2004).

BPP tenaga listrik merupakan kumpulan biaya yang diperhitungkan (allowable) dalam perhitungan BPP atau masuk dalam kategori allowable cost (hanya biaya yang berhubungan saja, yang tidak dapat dipisahkan dalam menghasilkan tenaga listrik yang dapat dimasukkan) untuk dihitung secara hati-hati sesuai dengan prinsip wajar, konsisten dan transparan (Depkeu, 2004).

Tujuan penelitian ini adalah untuk menentukan besaran keseluruhan biaya pokok penyediaan(BPP) tenaga listrik, menentukan besaran BPP tenaga listrik per jenis tegangan dan menentukan besaran BPP-TL per golongan pelanggan pada PT.PLN (PERSERO) sistem Sulseltrabar.

\section{Kajian Teori}

\section{Kerangka Pikir Pembiayaan}

Pembiayaan dalam suatu sistem tenaga listrik terlebih dahulu perlu untuk dipetakan agar pemahaman mengenai kerangka pembiayaan dapat lebih terstruktur dengan baik. Adapun kerangka pikir pembiayaan dalam suatu sistem tenaga listrik dapat dilihat pada gambar 1 (Depkeu, 2004). Dalam gambar ini, dijelaskan mengenai suatu bagan sistem tenaga listrik dari aspek pembiayaan. Bagan tersebut menginformasikan bahwa pembiayaan dalam suatu sistem tenaga listrik dapat dibagi menjadi tiga macam, yaitu pembiayaan dari sisi pembangkit, transmisi, dan distribusi. Pembiayaan tersebut dipandang dari aspek fungsi dalam suatu sistem tenaga listrik. Selanjutnya, pembiayaan dalam suatu sistem tenaga listrik dapat pula dipandang dari aspek unsur penyusunnya. Pada bagan tersebut diperlihatkan bagaimana pembiayaan sistem tenaga listrik jika disusun berdasarkan unsur komponen-komponen pembiayaan, yaitu biaya modal, biaya operasi dan pemeliharaan dan biaya bahan bakar (Depkeu, 2004).

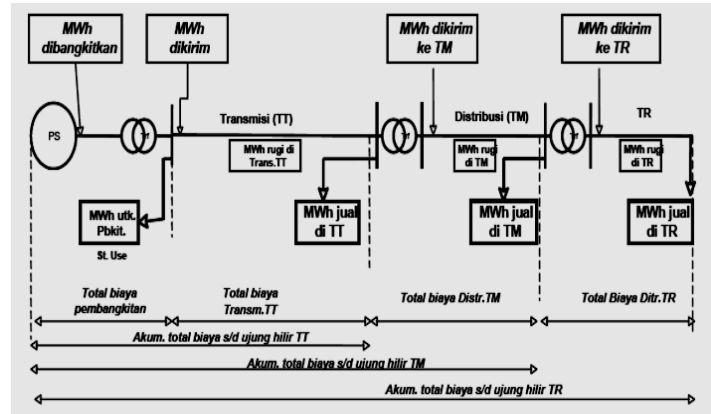

Gambar 1. Skema diagram kerangka pikir pembiayan sistem tenaga listrik

(Sumber : Depkeu, 2004)

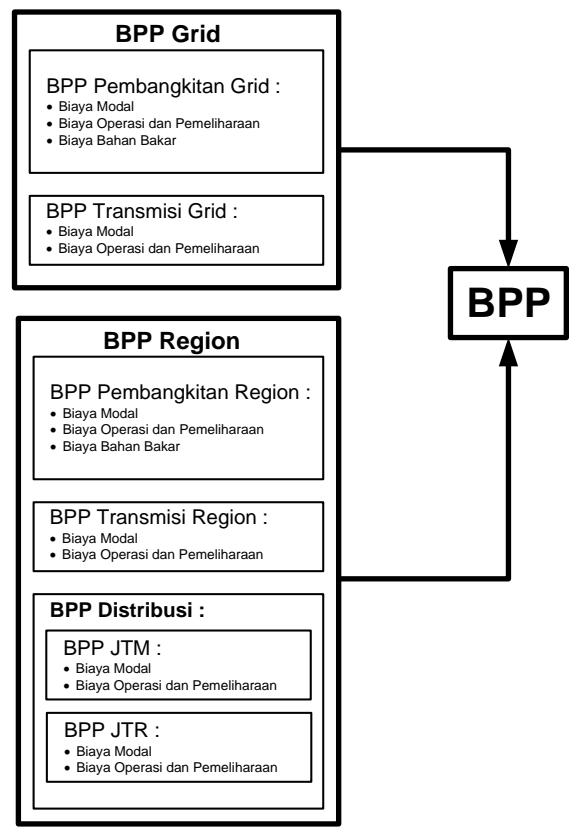

Gambar 2. Komponen pembiayaan untuk perhitungan BPP (Sumber : Depkeu, 2004)

Tenaga listrik merupakan komoditas yang memiliki sifat spesifik. Oleh karena itu penentuan harga jual tenaga listrik juga memiliki sedikit perbedaan jika dibandingkan dengan komoditi konvensional. Karena hal itulah, dalam suatu penentuan harga jual tenaga listrik diperlukan suatu mekanisme alokator. Alokator tersebut berperan untuk menentukan biaya yang akan dibebankan pada setiap golongan konsumen karena pola konsumsi konsumen akan sangat berpengaruh pada pembiayaan produksi (UGM, 2006). 


\section{Komponen Pembiayaan}

Dalam perhitungan pembiayaan, komponenkomponen biaya yang mempengaruhi dapat dianalisis secara parsial. Adapun pengelompokan komponen tersebut dapat sedikit berbeda, sesuai dengan metode analisis pembiayaan yang digunakan. Komponen-komponen pembiayaan tersebut antara lain biaya modal, biaya operasional dan pemeliharaan, dan biaya bahan bakar (Permen Keuangan, 2005).

\section{Metode Accounting Based}

Metode ini berasumsi bahwa biaya pokok suatu produksi merupakan biaya total yang dibutuhkan untuk memproduksi. Tenaga listrik dapat pula dipandang sebagai suatu komoditas sehingga asumsi tersebut dapat dianalogikan pada usaha penyediaan tenaga listrik (Permen Keuangan, 2005).

\section{Komponen Pembiayaan dengan Metode Accounting Based}

Informasi akuntansi penuh adalah seluruh aktiva, seluruh pendapatan yang diperoleh, dan/atau seluruh sumber yang dikorbankan suatu objek informasi. Dari definisi informasi akuntansi penuh ini dapat ditarik kesimpulan sebagai berikut (Permen Keuangan,2005):

a. Unsur yang membentuk informasi akuntansi penuh adalah total aktiva, total pendapatn, dan/atau total biaya. Jika informasi akuntansi penuh berupa aktiva maka informasi ini disebut dengan aktiva penuh (full assets). Jika informasi akuntansi penuh berupa seluruh sumber yang dikorbankan untuk suatu objek informasi, maka informasi ini disebut dengan biaya penuh (full costs).

b. Informasi akuntansi penuh selalu bersangkutan dengan objek informasi. Dalam hubungannya dengan objek informasi, informasi akuntansi penuh merupakan informasi akuntansi langsung yang terjadi dalam objek informasi tertentu ditambah dengan bagian yang adil informasi akuntansi tidak langsung yang dibebankan kepada objek informasi. Jika informasi akuntansi penuh berupa aktiva, maka aktiva penuh adalah aktiva langsung yang bersangkutan dengan objek informasi ditambah dengan bagian yang adil aktiva tidak langsung yang menjadi tanggung jawab objek informasi tersebut. Jika informasi akuntansi penuh berupa biaya, biaya penuh adalah biaya langsung objek informasi ditambah bagian yang adil biaya tidak langsung yang menjadi beban objek informasi tersebut.

\section{Komponen Pembiayaan Tenaga Listrik Berdasarkan SK Mentri}

Komponen pembiayaan listrik terdiri dari (UGM, 2006):

a. Pembelian tenaga listrik termasuk sewa diesel

b. Biaya bahan bakar yang terdiri dari Bahan Bakar Minyak (BBM), gas alam, panas bumi, batubara, minyak pelumas, eksplorasi dan pemeliharaan air dan biaya retribusi air permukaan

c. Biaya pemeliharaan yang terdiri dari material dan jasa borongan.

d. Biaya kepegawaian dan biaya administrasi dan penyusutan atas aktiva tetap operasional.

e. Biaya pinjaman yang digunakan untuk penyediaan tenaga listrik.

Perhitungan BPP dengan metode Accounting Based merupakan total biaya untuk penyediaan tenaga listrik dibagi dengan energi yang tersalurkan. Total biaya penyediaan tenaga listrik meliputi biaya pembelian tenaga listrik dan sewa pembangkit, biaya bahan bakar, biaya operasional dan pemeliharaan, biaya pegawai, biaya administrasi, biaya penyusutan dan biaya pinjaman. Sedangkan energi yang tersalurkan adalalah energi yang diterima dikurangi dengan susut energi (Permen Keuangan,2005).

$$
\begin{aligned}
\mathrm{BPP}_{\text {Total }}= & \mathrm{BPP}_{\text {Pembangkit }}+\mathrm{BPP}_{\text {Transmisi }} \\
& +\mathrm{BPP}_{\text {Distribusi }}
\end{aligned}
$$

$\mathrm{BPP}_{\text {Total }}$ adalah total biaya untuk penyediaan tenaga listrik ( $\mathrm{Rp})$ dan $\mathrm{BPP}_{\text {Pembangkit }}$ adalah biaya pembelian tenaga listrik dan sewa pembangkit ditambah dengan biaya bahan bakar, biaya operasi dan pemeliharaan pembangkit (material dan jasa borongan), biaya kepegawaian pembangkit, biaya administrasi pembangkit, biaya penyusutan pembangkit dan biaya pinjaman pembangkit. 


\section{DINAMIKA Jurnal Ilmiah Teknik Mesin}

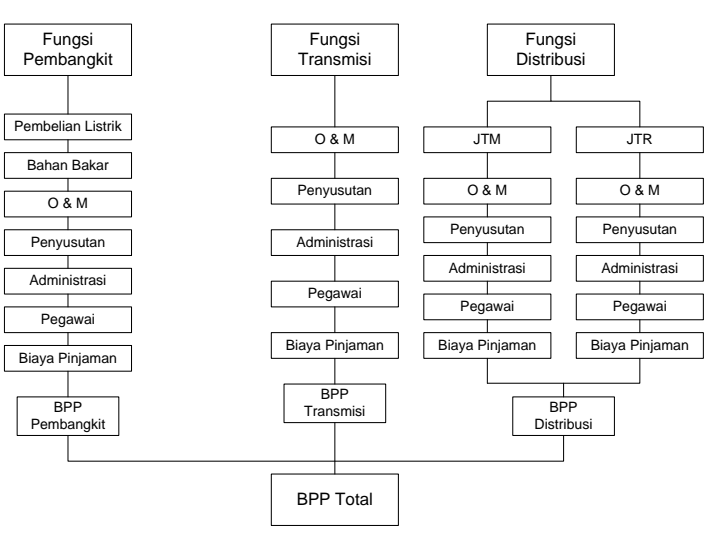

Gambar 3. Komponen-komponen pembiayaan Metode Accounting Based

(Sumber : Permen Keuangan, 2005)

$\mathrm{BPP}_{\text {Transmisi }}$ adalah biaya operasi dan pemeliharaan (material dan jasa borongan) transmisi ditambah biaya kepegawaian transmisi, biaya administrasi transmisi, biaya penyusutan transmisi dan biaya pinjaman transmisi(Rp)

$\mathrm{BPP}_{\text {Distribusi }}$ adalah biaya operasi dan pemeliharaan (material dan jasa borongan) distribusi ditambah biaya kepegawaian distribusi, biaya administrasi distribusi, biaya penyusutan distribusi dan biaya pinjaman distribusi(Rp).

\section{BPP Berdasar Golongan Pelanggan}

Dari metode formula perhitungan BPP di atas, dapat dihasilkan nilai BPP total. Kemudian, dari BPP total tersebut dapat dialokasikan menjadi BPP per jenis tegangan, yang kemudian dapat dialokasikan lagi menjadi BPP per golongan tarif S.1, S.2, S.3, R.1, R.2 dan seterusnya. Untuk lebih jelas mengenai alokasi ini dapat dilihat pada gambar 4.

Persamaaan matematis untuk biaya tetap pergolongan pelanggan dapat dijelaskan sebagai berikut,

$\mathrm{B}_{\text {tetap per golongan pelanggan }(\mathrm{Rp})}=$

$\mathrm{VA}_{\text {Jenis golongan pelanggan/total VA seluruh jenis pelanggan) }}$

X $\quad \mathrm{B}_{\text {tetap BPP total(Rp) }}$
$\mathrm{B}_{\text {variabel pergolongan pelanggan }(\mathrm{Rp})}=$

$\mathrm{R}_{\text {(kWh golongan pelanggan } / \mathrm{kWh} \text { total seluruh golongan pelanggan) }}$

X B $_{\text {variabel BPP total(Rp) }}$

$\mathrm{BPP}_{\text {per golongan pelanggan }(\mathrm{Rp} / \mathrm{kWh})}=$

$$
\frac{\mathrm{B}_{\text {tetap gol .plg }}+\mathrm{B}_{\text {variabel gol .plg }}}{\text { Vol. Penjualan pergolongan pelanggan }(\mathrm{kWh})}
$$

Dimana B adalah biaya, dan $\mathrm{R}$ adalah rasio.

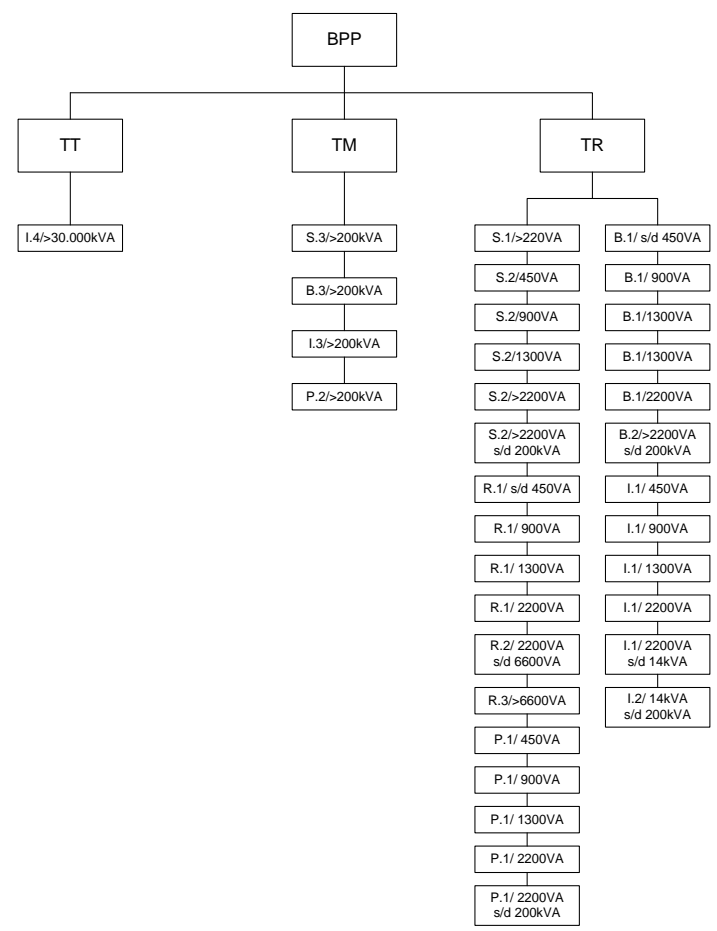

Gambar 4 . Alokasi BPP per golongan tarif (Sumber : Permen Keuangan, 2005)

\section{Metode Penelitian}

Data yang digunakan dalam penelitian ini adalah data realisasi biaya operasi periode 1 Januari sampai dengan 31 Desember 2007 di PT. PLN (PERSERO) Wilayah Sulseltrabar. Data tersebut berupa produksi dan penjualan tenaga listrik tahun 2007, daya tersambung (kVA) dan pemakaian energi (kWh) dari Januari-Desember 2007 (TULIII-09-2007). 


\section{DINAMIKA Jurnal Ilmiah Teknik Mesin}

Alat yang digunakan untuk menganalisis data adalah seperangkat komputer yang terdiri dari perangkat keras dan perangkat lunak. Aspek perangkat keras seperti Processor Pentium IV, memori RAM (256) MB dan flash disk. Perangkat lunak yang digunakan adalah program Microsoft Word 2007 dan Microsoft Excel 2007. Teknik yang digunakan dalam pengambilan data adalah metode dokumentasi, dimana data yang diambil adalah data kuantitatif yaitu data yang berwujud angkaangka. Diagram alir pelaksanaan penelitian ini adalah sebagai berikut,

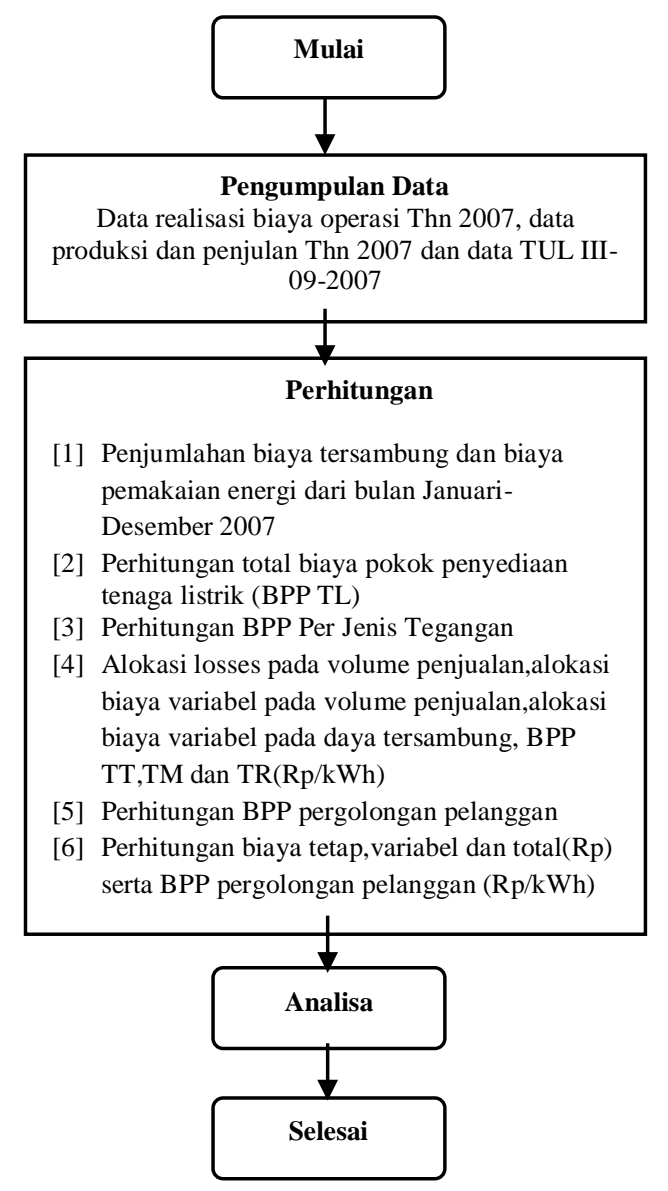

Gambar 5. Diagram alir pelaksanaan penelitian

\section{Hasil dan Pembahasan}

Total biaya pada fungsi pembangkit, transmisi dan distribusi sistem Sulseltrabar Tahun 2007 diperlihatkan pada gambar di bawah ini

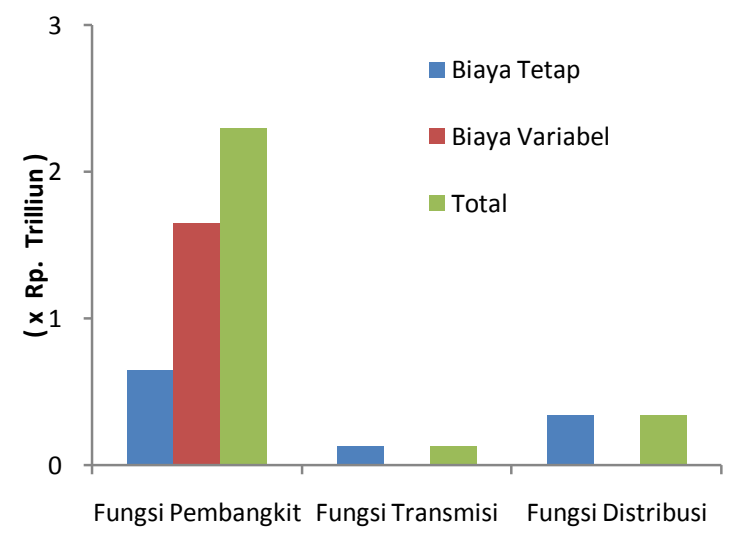

Gambar 6. BPP-TL fungsi pembangkit sistem,transmisi dan distribusi Sulseltrabar tahun 2007

Biaya Pokok Penyediaan (BPP) tenaga listrik keseluruhan sistem Sulseltrabar Tahun 2007 merupakan total BPP, meliputi BPP Pembangkit, BPP Transmisi dan BPP distribusi. BPP total sistem sulseltrabar tahun 2007 diperlihatkan pada gambar dibawah ini

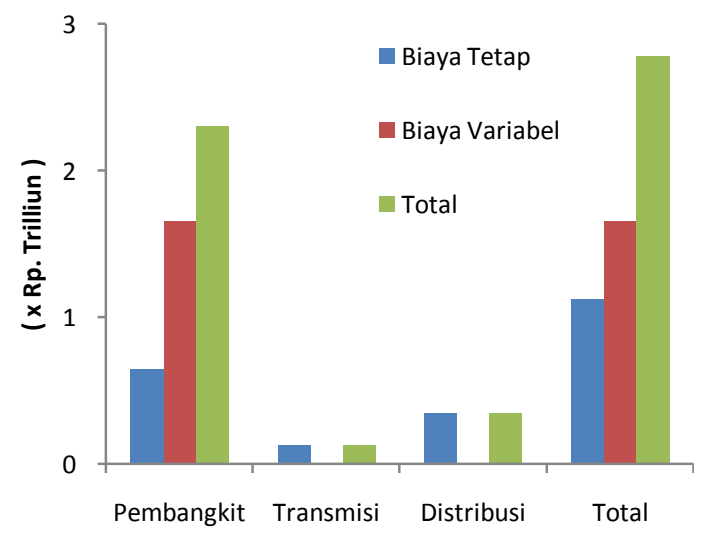

Gambar 7. BPP total sistem Sulseltrabar tahun 2007

Dari gambar di atas dapat dilihat bahwa biaya variabel, yang meliputi biaya bahan bakar dan minyak pelumas sistem Sulseltrabar tahun 2007 mempunyai presentase terhadap total BPP sebesar sekitar 59\%, sedangkan biaya tetap memiliki presentase sebesar sekitar $41 \%$.

\section{Perhitungan BPP Per Jenis Tegangan}

Pada bagian berikut akan dipresentasikan perhitungan BPP per-jenis tegangan. Pemakaian energi $(\mathrm{kWh})$ dari bulan Januari sampai bulan Desember 2007 adalah $8.300 \mathrm{kWh}$. 


\section{DINAMIKA Jurnal Ilmiah Teknik Mesin}

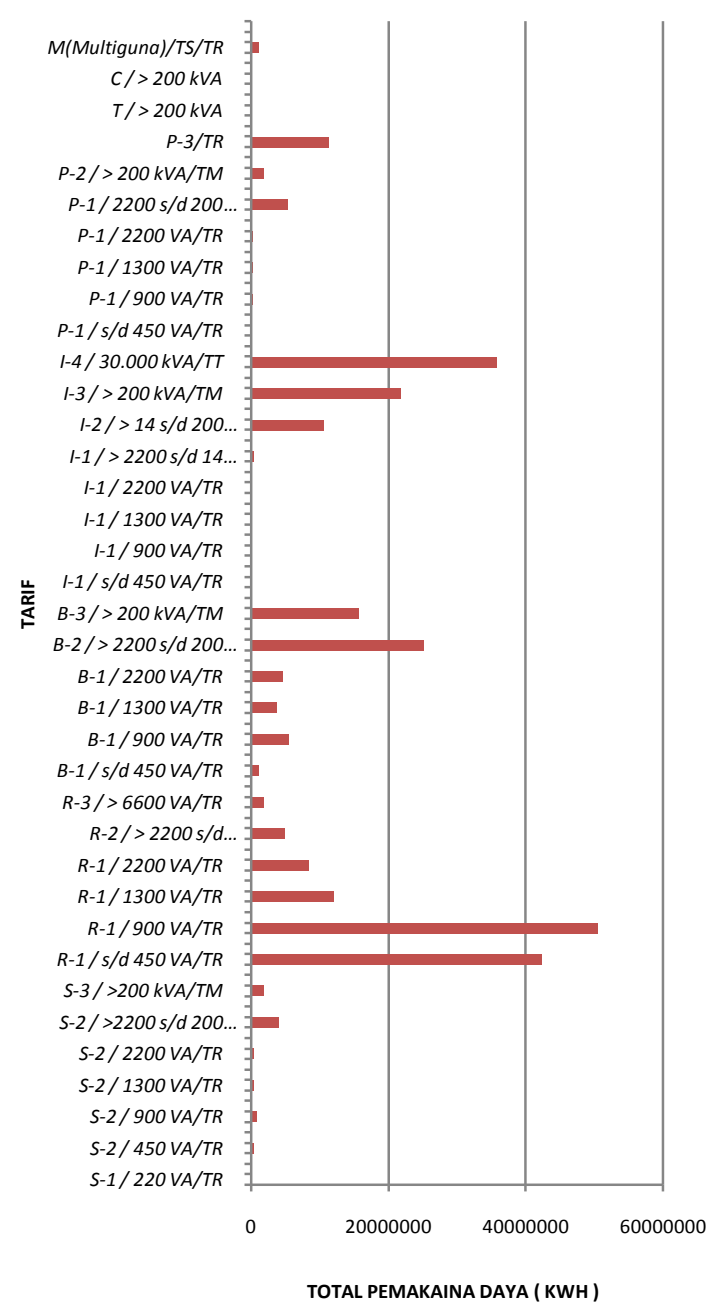

Gambar 8. Total kWh per golongan pelanggan sistem Sulseltrabar tahun 2007

Seperti diketahui sebelumnya nilai BPP total sistem Sulseltrabar tahun 2007 adalah sekitar Rp $2,78 \mathrm{~T}$ dan total volume penjualan $(\mathrm{kWh})$ adalah sekitar $2,7 \times 10^{9} \mathrm{kWh}$.

Volume penjualan ini dibagi ke dalam volume penjualan pelanggan untuk tiga aspek, meliputi TT,TM dan TR. Volume pelanggan TT adalah $358 \times 10^{6} \mathrm{kWh}$, volume pelanggan $\mathrm{TM}$ adalah $412 \times 10^{6} \mathrm{kWh}$ dan volume pelanggan TR adalah $1,9 \times 10^{9} \mathrm{kWh}$.

Berdasarkan metode accounting based dengan asumsi perhitungan realisasi biaya operasi sistem kelistrikan Sulseltrabar tahun 2007 dikatakan bahwa loses distribusi dialokasikan $25 \%$ untuk distribusi TM dan $75 \%$ untuk distribusi TR, sehingga:
Loses $_{\text {Distribusi TM }}=(25 / 100) \times 7,7 \%=1,90 \%$

Loses $_{\mathrm{TR}} \quad=(75 / 100) \times 7,7 \%=5,80 \%$

Sehingga volume penjualan per-jenis tegangan adalah

$$
\begin{aligned}
& =(1+0,051) \times 358.386 .283 \mathrm{kWh} \\
& =376 \times 10^{6} \mathrm{kWh}
\end{aligned}
$$

Volume penjualan TM terhadap alokasi losses (kWh) adalah

$$
\begin{aligned}
& =(1+0,0190) \times 412.605 .693 \\
& =420 \times 10^{6} \mathrm{kWh}
\end{aligned}
$$

Volume penjualan TR terhadap alokasi losses (kWh) adalah

$$
\begin{aligned}
& =(1+0,0580) \times 1.955 .733 .642 \\
& =2 \times 10^{9} \mathrm{kWh}
\end{aligned}
$$

Total kWh terhadap alokasi loses adalah Rp. 2,8 $\mathrm{x} 10^{9} \mathrm{kWh}$. Alokasi biaya variabel pada TT adalah Rp. $217 \times 10^{9}$, alokasi biaya variabel pada TM adalah Rp. 242. $\times 10^{9}$ dan alokasi biaya variabel pada TR adalah Rp. 1,193 x10

Langkah awal untuk menghitung kVA pada setiap jenis tegangan adalah dengan menghitung $\mathrm{kVA}$ total pada sistem Sulseltrabar tahun 2007. Untuk mendapatkan kVAtotal dengan menghitung terlebih dahulu menghitung KVA pergolongan pelanggan. Nilai kVAtotal adalah

$$
\begin{aligned}
\mathrm{VA}_{\text {total }} & = & \mathrm{VA}_{\text {Januari-Desember }} \\
& = & 16.600 \mathrm{VA} \text { atau } 16,6 \mathrm{kVA}
\end{aligned}
$$

Total daya tersambung sistem Sulseltrabar tahun 2007 sebesar $18 \times 10^{9}$ VA. Daya tersambung untuk TT adalah $867 \times 10^{6} \mathrm{VA}$, daya tersambung untuk TM adalah $1,988 . \times 10^{9} \mathrm{VA}$ dan daya tersambung untuk TR adalah $15,8 \times 10^{9} \mathrm{VA}$. 


\section{DINAMIKA Jurnal Ilmiah Teknik Mesin}

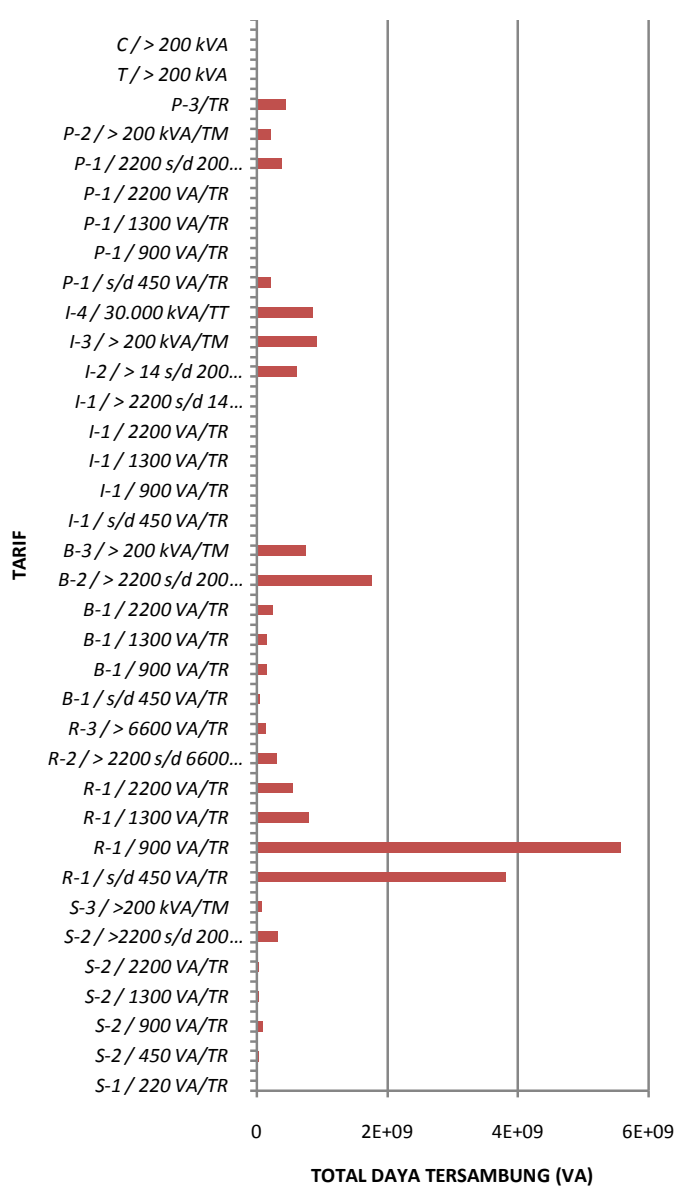

Gambar 9. Total daya tersambung (VA) sistem Sulseltrabar tahun 2007

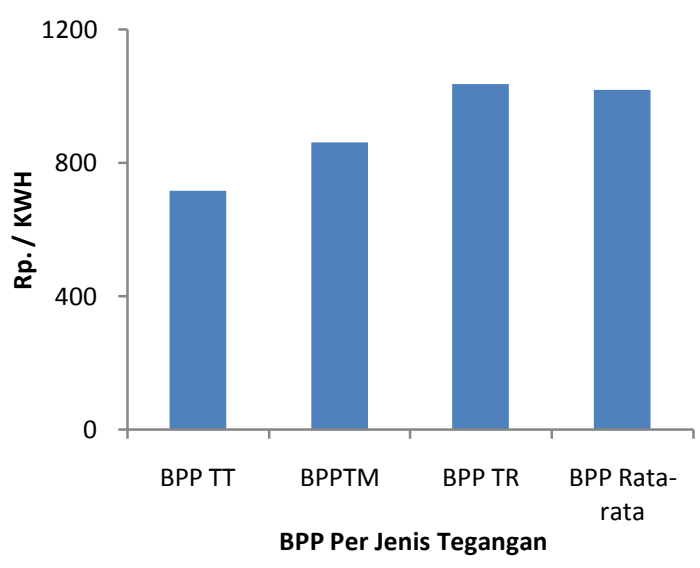

Gambar 10. BPP per jenis tegangan di sistem Sulseltrabar tahun 2007

BPP per-jenis tegangan didapatkan dengan menjumlahkan biaya tetap dan variabel per-jenis tegangan dibagi dengan energi per-jenis tegangan. BPP rata-rata didapatkan berdasarkan total BPP per jenis tegangan dibagi dengan total penggunaan energi. Biaya tetap per-jenis tegangan didapatkan dengan membagi kVA perp-jenis tegangan dengan KVA total dikalikan dengan total biaya tetap

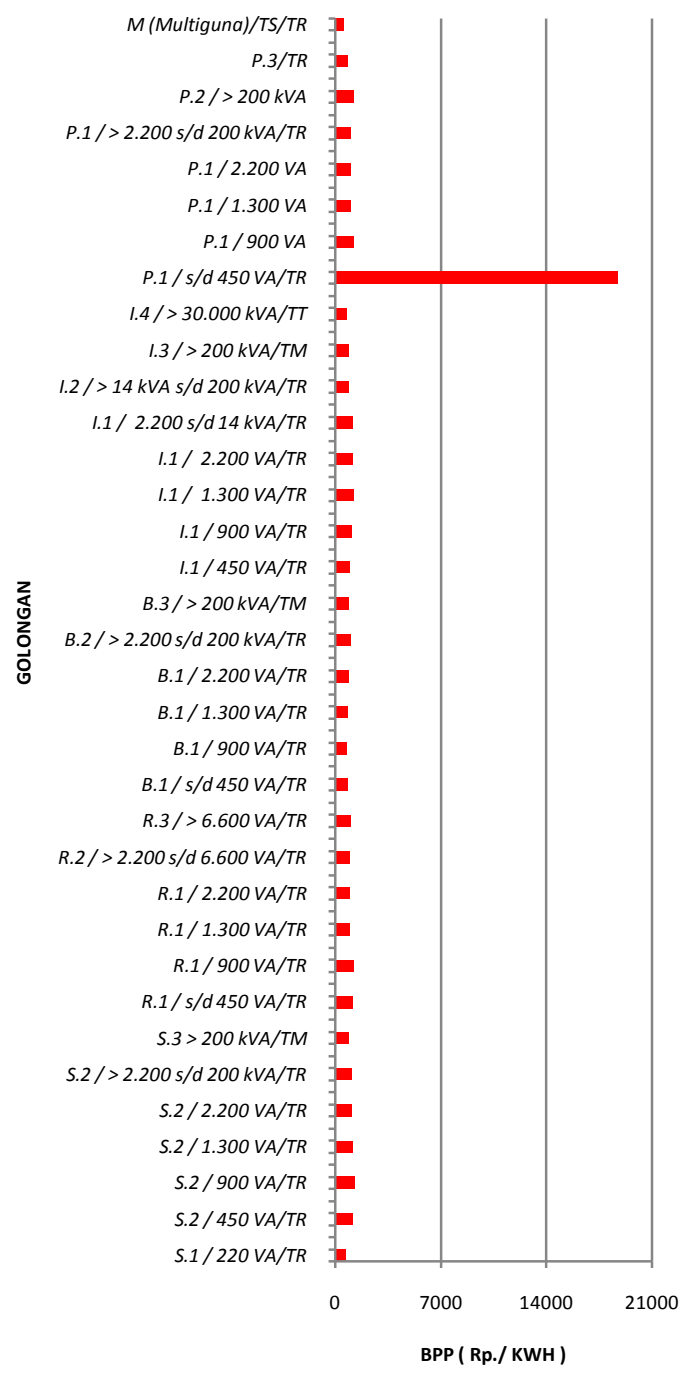

Gambar 11. BPP per golongan pelanggan sistem Sulseltrabar tahun 2007

Biaya tetap dialokasikan berdasarkan KVA tersambung, terdiri dari biaya tetap TT bernilai $\mathrm{Rp} 52 \times 10^{9}$, biaya tetap TM bernilai $\mathrm{Rp} 119 \times 10^{9}$ dan biaya tetap TR bernilai $\mathrm{Rp} 954 \times 10^{9}$. Sehingga $\mathrm{BPP}_{\mathrm{TT}}$ adalah $716 \mathrm{Rp} / \mathrm{kWh} . \mathrm{BPP}_{\mathrm{TM}}$ adalah $862 / \mathrm{kWh}, \mathrm{BPP}_{\mathrm{TR}}$ adalah $1.038 / \mathrm{kWh}, \mathrm{BPP}$ total perjenis tegangan adalah $\mathrm{Rp} 2,780 \times 10^{15}$ dan BPP rata-rata adalah $1.020 / \mathrm{kWh}$.

Pada BPP per-golongan pelanggan (golongan pelanggan S-1 220 VA), biaya tetap adalah Rp1.001.316 dan biaya variabel adalah 
Rp5.032.274. Biaya total pada Gol S.1 220 VA adalah biaya tetap Gol S.1 220VA ditambah biaya variabel Gol S1220VA, sebesar 726,939/kWh.

Dari perhitungan di atas, BPP terkecil terdapat pada golongan pelanggan multiguna. Hal ini disebabkan pelanggan ini menggunakan trafo sendiri, sehingga tidak dibebankan biaya tetap atas daya terpasang (VA). BPP dengan nilai tertinggi terdapat pada golongan P.1 s.d $450 \mathrm{VA}$ atau pelanggan industri pada jaringan tegangan rendah.

\section{Kesimpulan dan Saran}

Kesimpulan dalam penelitian ini adalah besaran BPP total pada PT.PLN (PERSERO) Wilayah Sulseltrabar rahun 2007 ditentukan oleh biaya pembelian tenaga listrik dan sewa pembangkit, biaya pemeliharaan, biaya kepegawaian, biaya administrasi, biaya penyusutan dan biaya pinjaman serta biaya non-BPP baik pada sisi pembangkit, transmisi dan ditribusi.

Selain itu, besaran BPP per-jenis tegangan pada PT.PLN (PERSERO) Wilayah Sulseltrabar tahun 2007 ditentukan oleh alokasi losses pada tegangan tinggi, tegangan menengah dan tegangan rendah, sedangkan BPP rata-rata ditentukan oleh total pemakaian energi pada ketiga jenis tegangan. Besaran BPP per-golongan pelanggan pada PT.PLN(PERSERO) Wilayah Sulseltrabar tahun 2007 ditentukan oleh daya yang terpasang dan pemakaian energi dari setiap golongan pelanggan.

Beberapa saran dari penelitian ini adalah supaya nilai BPP total dapat diketahui lebih rinci sebaiknya besaran setiap komponen yang mempengaruhi BPP Sistem Sulseltrabar pada tahun 2007 diambil dari data buku besar pada tahun 2007. Selain itu, untuk penentuan losses sebaiknya dengan melakukan studi optimal power flow, dimana losses yang didapatkan sebagai hasil dari terjaganya kondisi tegangan pada setiap bus serta optimal biaya bahan bakar tercapai.

Studi ini juga dapat dilanjutkan pada analisa sensitifitas $\mathrm{BPP}_{\mathrm{TL}}$ terhadap faktor internal dan external, dimana faktor internal adalah pengalihan sebagian volume dari jenis bahan bakar yang mahal ke bahan bakar yang lebih murah akibat pengaruh kenaikan harga bahan bakar, sedangkan faktor eksternal adalah pengaruh dari ekonomi makro.

\section{Daftar Pustaka}

Depkeu \& PLN. 2004, "Laporan Akhir Kajian Dampak Perubahan Trend Penggunaan Tenaga Listrik Pada Sektor Industri". Center For Energi and Power Studies(CEPS).

Permen Keuangan. 2005, "Permen Keuangan No.117/PMK.02/2005 tanggal 29 November 2005 tentang Tata Cara Penghitungan dan Pembayaran Subsidi Listrik"

UGM \& PLN. 2006, "Laporan Akhir kajian penyesuaian tarif dan penerapannya bagi pemegang kuasa usaha ketenagalistrikan(PKUK)".

PLN. 2007, "Data realisasi biaya operasi PT.PLN(PERSERO) Sistem Sulseltrabar Tahun 2007",

PLN, 2007, "Data biaya produksi daan penjualan PT.PLN(PERSERO) Sistem Sulseltrabar Tahun 2007"

PLN. 2007, "Data TUL III-09 THN 2007”

PLN. 2007, "Data BPP Perjenis tegangan PT.PLN(PERSERO) Wilayah Sulseltrabar Tahun 2007" 